\title{
Determinants of Labor Productivity in Emerging Markets: Evidence from Pre- and Post-Financial Crisis Mexico
}

\author{
Young-Hee Kang, and Kyunga $\mathrm{Na}^{*}$ \\ Keimyung Univerity, Republic of Korea
}

\begin{abstract}
Although the global financial crisis of 2008 had tremendous effects on global businesses, its impact on firm performance in emerging markets is unknown. To develop this knowledge, this study explores the factors that influenced labor productivity in emerging markets before and after the crisis. Using a sample of 2,061 Mexican firms that were collected by the World Bank in 2006 and 2010, this study investigates the relationships of bribery, informality, and corporate governance to labor productivity. The results show that, before the crisis, informality and foreign ownership were positively associated with labor productivity. On the other hand, after the crisis, bribery and informality are negatively related to labor productivity, while foreign ownership and external auditing make positive impacts on labor productivity. The findings imply that businesses need to improve the quality of their corporate governance and decrease bribery. Governments of emerging markets need to reduce the levels of informality.
\end{abstract}

Keywords: bribery; corporate covernance; emerging markets; global financial crisis; labor productivity

JEL classification: E26, F65, G34

* Corresponding author's e-mail: kyunga@gw.kmu.ac.kr 


\section{Introduction}

The global financial crisis of 2008 represents the worst financial crisis since the Great Depression of the 1930s (Neaime 2012), leading to global economic recession (Dal Bianco et al. 2017). The crisis has influenced the global economy and businesses in a variety of ways (Campello et al. 2010). For example, the US, as well as European and Asian countries, have suffered from depression for a while, which has constrained global businesses (Neaime 2012). In addition, the financial crisis is likely to increase the uncertainty of business environments, thus influencing business strategies and performance. Given that the crisis limited businesses in their activities, global businesses are now more constrained after the 2008 financial crisis than they were before the crisis (Campello et al. 2010). In particular, the global crisis greatly impacted transition economies, which have less-developed financial markets (Neaime 2012). Compared to developed economies, transition economies are more likely to have difficulties in accessing or obtaining financing (Alaimo et al. 2009). This implies that the global financial crisis of 2008 may have had more significant impacts on firm activities or performance in emerging markets. Moreover, as emerging markets are characterized by high levels of uncertainty, the 2008 financial crisis has contributed to increasing business risk.

Despite the tremendous effects of the financial crisis on emerging markets, much is unknown about the effects of financial constraints on businesses in emerging markets, because previous empirical research on financial constraints has focused on data from US public companies (Compello et al. 2010). Thus, the current study explores the impacts of the global financial crisis on emerging markets. Using a sample of Mexican companies, this research compares factors that influenced labor productivity in the pre- and post-financial crisis periods.

Among such factors are corporate bribery, informality, and weak corporate governance; these factors are regarded as major features of emerging markets (e.g., Mitton 2002; Cuervo-Cazurra 2006; Alaimo et al. 2009; Chen et al. 2009; Baik et al. 2015). Some of the scholars that have attempted to identify the determinants of labor productivity in emerging markets pay attention to these factors (e.g., Mitton 2002; Kang and Chung 2015). In emerging markets, financial markets and institutions are less developed (Alaimo et al. 2009); corruption is relatively severe (Schneider 2005; Cuervo-Cazurra 2006; Sanchez et al. 2008: 341); and the ratio of informal sectors to the national economy is relatively high (González and Lamanna 2007; Alaimo et al. 2009; Baik et al. 2015). As the 2008 financial crisis increased uncertainty and risk, the effects of the three factors on labor productivity may differ before and after the crisis. For example, the impact of the quality of governance on firm productivity may be bigger before the crisis. As businesses had more financial constraints directly after the crisis, weak corporate governance may have provided more negative signals to potential investors or customers before the crisis. On the other hand, firms with a good governance quality may have achieved better performance by proving their trustworthiness or gaining a good reputation from the markets.

There are several reasons for choosing the Mexican case to answer the study's research question. First, Mexico has been regarded as a fast-growing market in Latin America, because it has shown low labor costs, stable foreign exchange rates, a rela- 
tively high economy growth rate, and so on (Kwon et al. 2014). Second, Mexico is part of the North American economic zone, which includes the US and Canada. The global financial crisis of 2008 was triggered by a crisis in the subprime mortgage market in the US in 2007. The Mexican economy is greatly influenced by the US economy. According to Dooley and Hutchison (2009), Mexico had close economic and financial relations with the US, and the relations were stronger just after the financial crisis. Finally, Mexico has many of the important institutional features of emerging markets, such as high levels of corruption (e.g., TI2011; Kang and Chung 2015), informality (e.g., González and Lamanna2007; Alaimo et al. 2009; Kang and Chung 2015), low infrastructure (Kwon et al. 2014), and so on.

This study has several implications. First, the findings of this research contribute to the literature on the effects of the global financial crisis on business productivity, by investigating the factors that influenced labor productivity after the crisis. In addition, this study contributes to the understanding of firm productivity in emerging markets by exploring the determinants of labor productivity before and after the crisis. Next, this study has useful implications for practitioners. For example, the findings suggest ideas for policy makers or governments of emerging markets to improve firm productivity. Further, this research will help businesses to develop managerial practices or business strategies by providing evidence to enhance firm performance.

This paper is organized as follows. In the next section, the theoretical background of the study is discussed. This is followed by the research methodology, analysis techniques, and results. The concluding section discusses the implications of the findings from the study, and suggests directions for further research.

\section{Literature Review}

\section{The Financial Crisis and Bribery Effects}

Bribery, called grease money, is a representative type of corruption (Lee and Weng 2013). The majority of bribery by firms is associated with government officials, since firms aim to obtain resources that are mainly controlled by the government (Luo 2005). Although bribery is common across many countries, it has been regarded as a critical feature of less developed economies or institutions (Rodriguez et al. 2005; CuervoCazurra 2006). However, the literature on corruption or bribery has provided inconsistent results on the effect of corruption on firm performance. Some studies assert that firms bribing government officials has a positive effect on firm performance (e.g., Lee and Weng 2013), while others claim that firm corruption is negatively related to firm performance (e.g., Kaufmann and Wei 1999; Wei 2000; Padgett and Morris 2005).

A financial crisis makes the business environment more uncertain and constrained. In order to obtain preferential treatment, bribes are paid to bribees such as government officials. This means that bribery may be costly for companies, and may affect firm performance. As business activities are constrained by the global financial crisis, the effects of bribery on firm performance may be different from before the crisis. For instance, firm bribery may be positively related to firm performance, in that bribery may make businesses offering bribes more likely to access resources that grant competitive advantages than their non-bribing counterparts. On the 
other hand, firm bribery may have negative effects on firm performance after the financial crisis. Paying bribes to officials may deteriorate organizational efficiency (Kaufman and Wei 1999), and firm bribery has negative impacts on employees' attitudes towards their leaders or organizations (Johnson and O'Leary-Kelly 2003). This suggests that, after the financial crisis, firm bribery may have had negative effects on labor productivity in emerging markets.

\section{The Financial Crisis and Informality Effects}

Informality plays a critical role in emerging economies, because such economies are likely to have a large number of unregistered businesses and significant employment in the informal sectors (Schneider and Enste 2000; Alaimo et al. 2009). There are different definitions of informality among scholars (Kang and Chung 2015). In this study, informality is related to unregistered businesses that are less likely to be monitored by the regulatory authority (e.g., González and Lamanna 2007; Amin 2011); while competition with informal rivals is relevant to firm level performance (Baik et al. 2015). More precisely, informality is defined as competition with unregistered rivals (González and Lamanna 2007; Amin 2011; Kang and Chung 2015).

High levels of informality mean that unregistered firms form a large part of an economy (Gonzalez and Lamanna 2007; Amin 2011). Djankov et al.'s (2005) findings imply that emerging markets tend to have larger informal economies, because regulatory burdens are positively associated with firm entry costs (Levie and Autio 2011). Firms in the informal sector can benefit from low costs because they are less concerned with paying taxes and following regulations or laws (Baik et al. 2015). It is likely that companies in the formal sector that compete with unregistered rivals are more prone to suffer from such disadvantages than their counterparts. The business risk increased more after the crisis than before (Campello et al. 2010), and the business environment of transition economies has deteriorated more since the crisis than those of developed economies (Neaime 2012). This implies that having unregistered competitors should be negatively associated with organizational performance in emerging markets, where regulatory burdens are relatively high. In addition, some studies provide evidence that competition with firms in the informal sector has negative effects on firm performance (e.g., Kang and Chung 2015).

\section{The Financial Crisis and Corporate Governance Effects}

Some studies address the critical role of corporate governance in firm value, in emerging markets (e.g., La Porta et al. 2000; Mitton 2002). Specifically, corporate governance influenced the firm value of East Asian transition economies during the financial crisis of 1997 (Johnson et al. 2000). According to Mitton (2002), corporate governance played a critical role in firm performance in Indonesia, South Korea, Malaysia, the Philippines, and Thailand during the 1997 East Asian financial crisis. In particular, Mitton (2002) focuses on the relations of disclosure quality, ownership structure, and corporate diversification among the elements that indicate corporate governance. From these, disclosure quality and ownership structure were chosen as indicators of corporate governance, because emerging markets are likely to be managed by large controlling shareholders, and to have a low disclosure quality (Chen et al. 2009). 
Some studies consider an external audit as a proxy of the disclosure quality, because it implies the credibility of a firm's financial reports (e.g., Mitton 2002; Barako et al. 2006). This study employs the external audit as an indicator of corporate governance, because it is more likely to increase the transparency of a company's financial statements than an internal audit will. As emerging markets have relatively weak financial regulations or institutions, external audits may be more likely to increase the perceived disclosure quality, even though the actual disclosure quality is not high. Further, this research uses the rate of foreign ownership as another indicator of corporate ownership. Foreign shareholders may engage in monitoring managerial decisions, rather than obtaining corporate governance in transition economies (Chen et al. 2009). Some studies report that a large foreign shareholding may have positive effects on firm performance, by preventing top management from engaging in opportunistic behavior in emerging markets (e.g., Chen et al. 2009).

Considering all things, corporate governance's quality may have a positive relationship with firm performance in the preand post-financial crisis periods. However, this relationship may be more obvious after the crisis than before the crisis. The financial crisis made it more difficult for businesses to obtain financial resources than before the crisis, because it increased the uncertainty of the business environment. The financial crisis increased investors' fears and shrank the financial markets, which in turn led to their economic downfall. Businesses with good corporate governance are likely to have a good reputation, which may contribute to firm performance during the crisis.

\section{Methods}

\section{Data Collection}

Mexican samples from the World Bank Enterprise Survey (WBES) dataset were used to determine which of the factors that affect labor productivity differ before and after the 2008 financial crisis. Since the early 2000s, the World Bank has surveyed businesses in transition economies, thus providing a variety of information about business environments (financing, corruption, infrastructure, etc.) and firm performance measures. ${ }^{1}$ In terms of Mexico, the World Bank has performed three rounds of surveys, in 2002, 2006, and 2010, respectively. For the purpose of this study, data from 2006 and 2010 were used, because the 2002 data is less relevant to the global financial crisis.

\section{Sampling}

Sample companies were selected from the Mexican data of the WBES in two steps: 1) The businesses which have participated in the survey in 2006 or 2010 were included in the sample and; 2) observations with missing values for the current study were excluded. Using these criteria, a total of 2,061 firms were obtained. The features of the overall sample are presented in Table 1. Of the overall sample, 54.73 percent $(1,128)$ companies have been surveyed in 2006 and 45.26 percent (933) in 2010, respectively. In terms of their industries, 54.2 percent $(1,117)$ of the firms are in manufacturing and other, 29.94 percent (617) in service, 10.67 percent (220) in construction, and 5.19 percent (107) in wholesale \& retail. The sample has 38.86 percent (801) micro-small firms (no more than 20 employees), 31.49 percent (649)

${ }^{1} \mathrm{~A}$ detailed description on the WBES and related data are available at http://www.enterprisesurveys.org. 
Kangand $\mathrm{Na}$

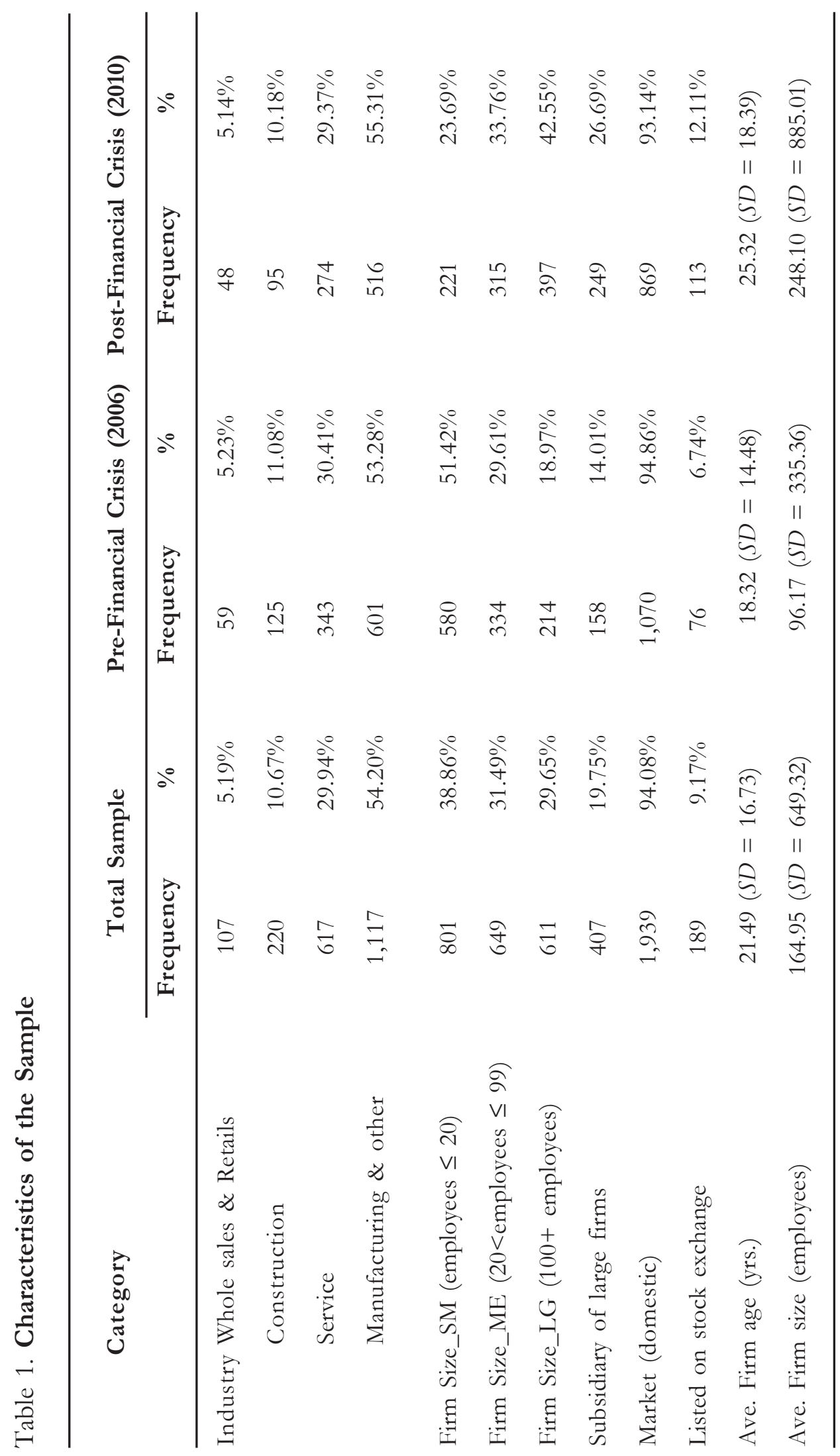


medium firms $(20 \leq$ employees $\leq 99)$, and 29.65 percent (611) large firms $(100+\mathrm{em}-$ ployees), respectively. The average firm age is $21.49(S D=16.73)$ years.

\section{Estimations and Measures}

For the purpose of this research, Equation (1) was constructed, where the dependent variable is Labor Productivity, proxied by the natural logarithm of sales per employee; the test variable is Bribery, proxied by an indicator variable which is one if a firm is involved in any kind of informal gift or payment, and zero otherwise. Informality is proxied by an indicator variable which is one if a firm competes with informal (or unregistered) firms, and zero otherwise; OWN_Foreign is proxied by an indicator variable that represents the percentage owned by foreign individuals, companies or organizations; and External Audit represents a test variable that is one if an external auditor audited a firm's financial statements, and zero otherwise.

Equation (1) was calculated based on two subsamples divided by the incidence of the global financial crisis in 2008: fiscal year 2006 as the period before the financial crisis (hereinafter pre-financial crisis), and fiscal year 2010 as the period after the financial crisis (hereinafter post-financial crisis). Then, the coefficients of the test variables were compared. For example, Bribery $\left(b_{1}\right)$ from each regression is used to examine the difference in coefficients of Bribery between the pre-financial crisis and the post-financial crisis. Given that bribery can reduce labor productivity, the coefficient estimate on the test variable Bribery is expected to be negative in both periods. However, the magnitudes may be different. If $b$ from the pre-financial crisis is less than $b_{1}$ from the post-financial crisis, bribery by a firm has harmed labor produc- tivity more in the period before the financial crisis, and vice versa. Likewise, Informality $\left(b_{2}\right)$, OWN_Foreign $\left(b_{3}\right)$, and External Audit $\left(b_{4}\right)$ from each regression are compared to examine the difference in coefficients on these test variables between the pre- and post-financial crisis.

Labor $\quad \alpha+\beta_{1}$ Bribery $+\beta_{2}$ Informality

Productivity $=+\beta_{3}$ OWN_Foreign $+\beta_{4}$ External

$$
\begin{aligned}
& \text { audit }+\beta_{5} \text { AGE }+\beta_{6} \text { Size_SM } \\
& +\beta_{7} \text { Size_ME }+\beta_{8} \text { SUB } \\
& +\beta_{9} \text { EXPORT }+\beta_{10} \text { Ext_FIN } \\
& +\beta_{11} \text { TAX_INSPECT }+\beta_{12} \text { LIST } \\
& +\beta_{13} \text { MKT }+\beta_{14} \text { IND_WR } \\
& +\beta_{15} \text { IND_CONST } \\
& +\beta_{16} \text { IND_SERVICE } \\
& +\beta_{17} \text { Post period }+\varepsilon
\end{aligned}
$$

where,

Labor productivity $=$ Natural logarithm of sales per employee.

Bribery $=\quad$ One if a firm is involved in any kind of informal gift or payment, and zero otherwise.

Informality $=\quad$ One if a firm competes with informal (or unregistered) firms, and zero otherwise.

OWN_Foreign $=$ Percent owned by foreign domestic individuals, companies, or organizations.

External audit $=$ One if a firm's financial statements were audited by an external auditor, and zero otherwise.

$A G E=\quad$ Natural logarithm of firm age. 


\begin{abstract}
SIZE_SM $=$ One if the total number of employees is less than 21, and zero otherwise.
\end{abstract}

SIZE_ME $=\quad$ One if the total number of employees falls between 21 and 99, and zero otherwise.

$\begin{array}{ll}S U B= & \begin{array}{l}\text { One if a firm is part of a } \\ \text { large firm, and zero oth- } \\ \text { erwise. }\end{array} \\ \text { EXPORT }= & \begin{array}{l}\text { percent of export from } \\ \text { sales. }\end{array} \\ \text { EXT_FIN }= & \begin{array}{l}\text { percent of external fi- } \\ \text { nancing. }\end{array}\end{array}$

TAX_INSPECT $=$ One if the firm has a tax inspection, and zero otherwise.

LIST $=\quad$ One if a firm is publicly listed and zero otherwise.

$M K T=\quad$ One if the main market is a domestic market, and zero otherwise.

$I N D \_W R=\quad$ One if a firm belongs to the wholesale or retail industry, and zero otherwise.

IND_CONST $=$ One if a firm belongs to construction industry, and zero otherwise.

IND_SERVICE $=$ One if a firm belongs to service industry, and zero otherwise, and

Post period $=\quad$ One if a firm belongs to the sample of 2010 , and zero otherwise.

Equation (1) also includes several control variables which may affect labor productivity, such as firm age, firm size, status of organization (subsidiary vs. independent firm), percentage of exports from sales, percentage of external financing in the total financed amount, status of tax inspection, listing status (listed firms vs. unlisted firms), the main market (domestic and international market), and industry.

\section{Results}

Table 2 summarizes the descriptive statistics of the variables, and Table 3 outlines the correlations between the variables. As seen in Table 3, bribery and informal competition are negatively related to labor productivity in the post-financial crisis $(p<0.001)$, whereas the relationship is unclear in the prefinancial crisis. On the other hand, external audit is positively associated with the labor productivity of both the pre- and post-crisis periods $(\phi<0.01)$.

The results of the Ordinary Least Square (OLS) models are presented in Table 4. In terms of the pre-financial crisis, bribery is negatively correlated with labor productivity, which is non-significant. In addition, informality is positively associated with labor productivity before the crisis, $\beta=0.30, p<0.05$. Foreign ownership is also positively related to labor productivity, $\beta=0.50, p<0.01$. On the other hand, external audit has non-significant effects on labor productivity.

However, bribery has a significant negative correlation with labor productivity after the financial crisis, with $\beta=-0.42, p<0.01$. Informality is negatively related to labor productivity, $\beta=-0.23, p<0.01$. Foreign ownership is positively related to labor productivity, $\beta=0.67, p<0.001$. Further, external audit has positive effects on labor productivity, $\beta=0.41, p<0.001$. 
Gadjah Mada International Journal of Business-Sept.-Dec., Vol.20,No.3, 2018

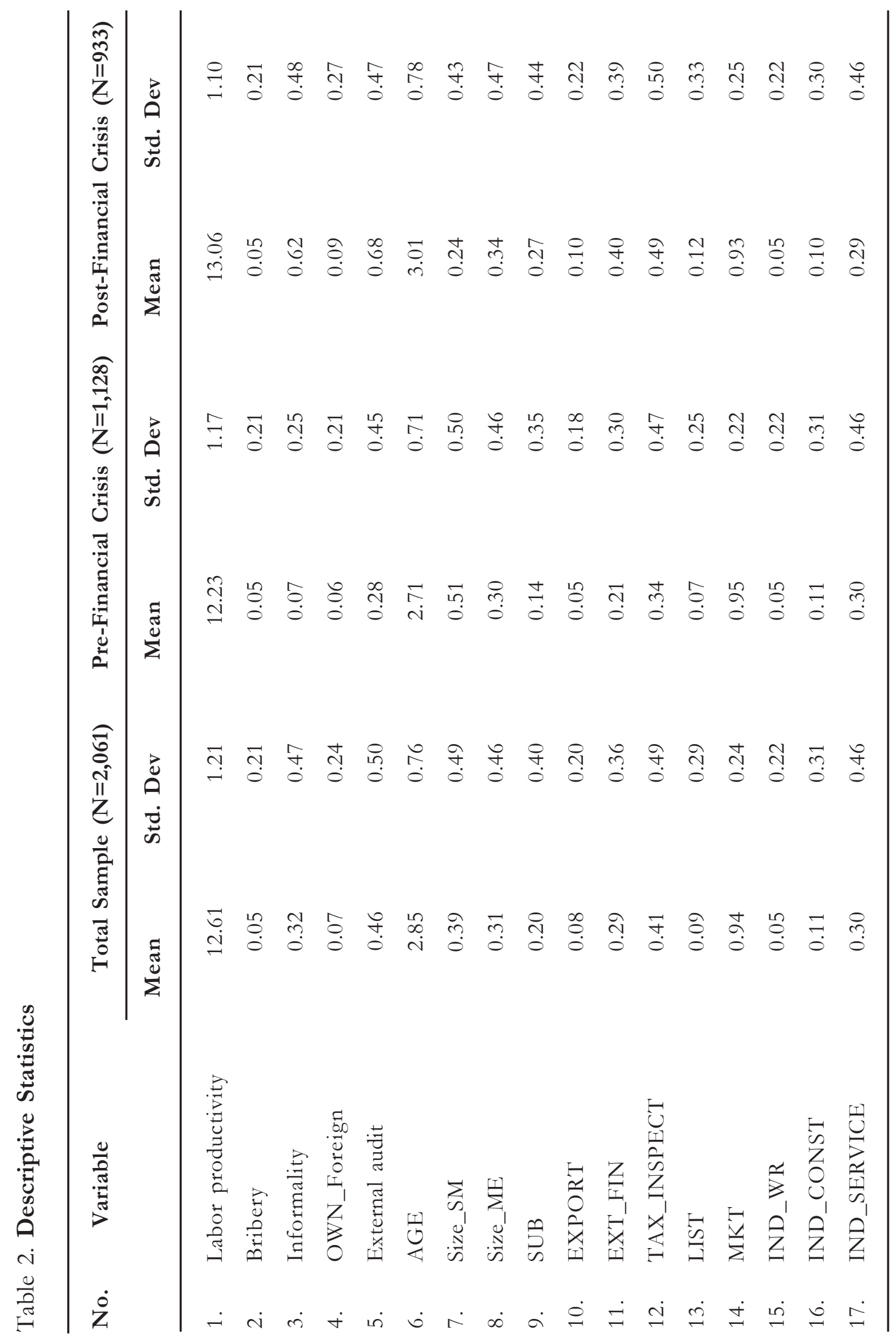




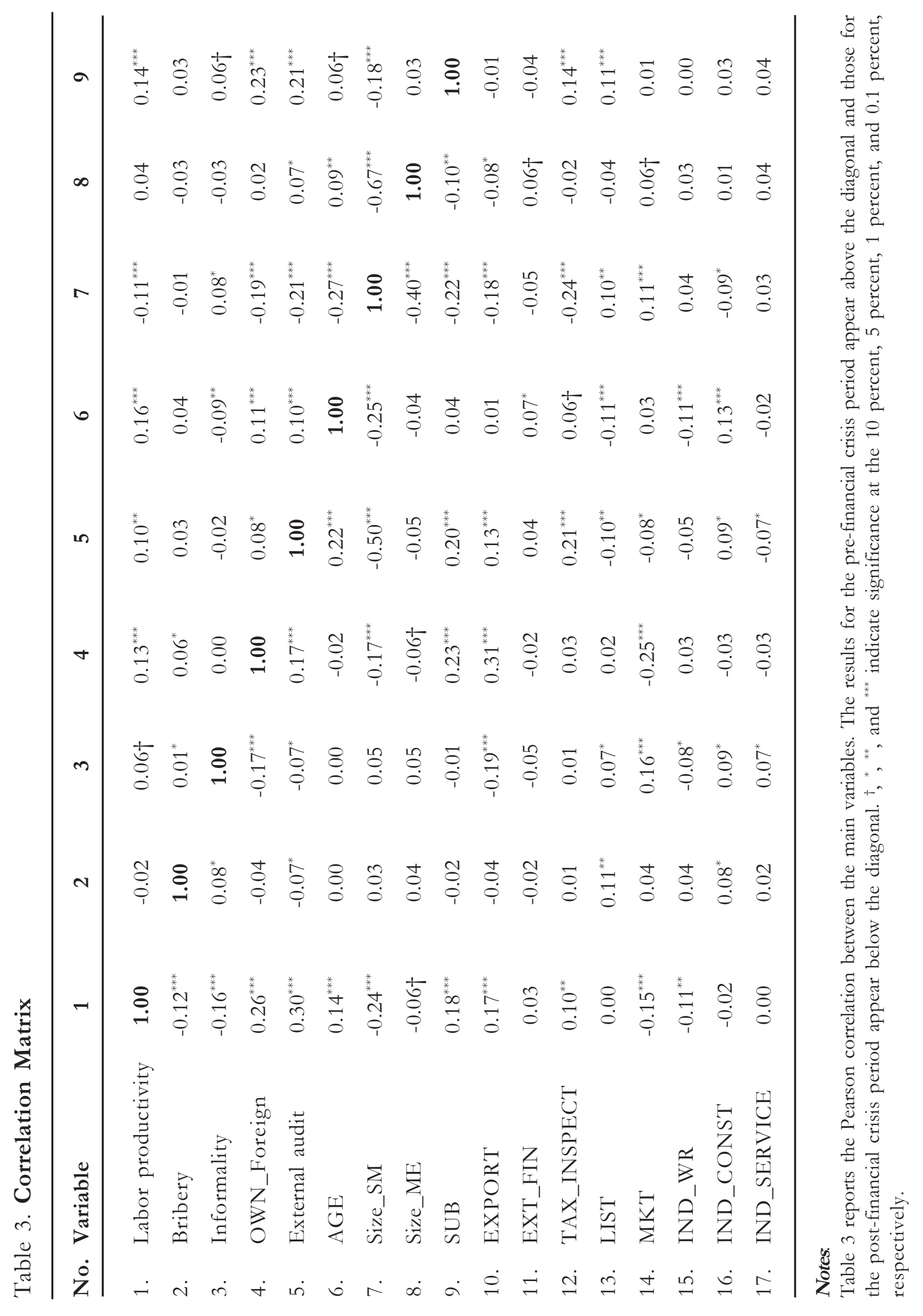


Gadjah Mada International Journal of Business-Sept.-Dec., Vol.20,No.3, 2018

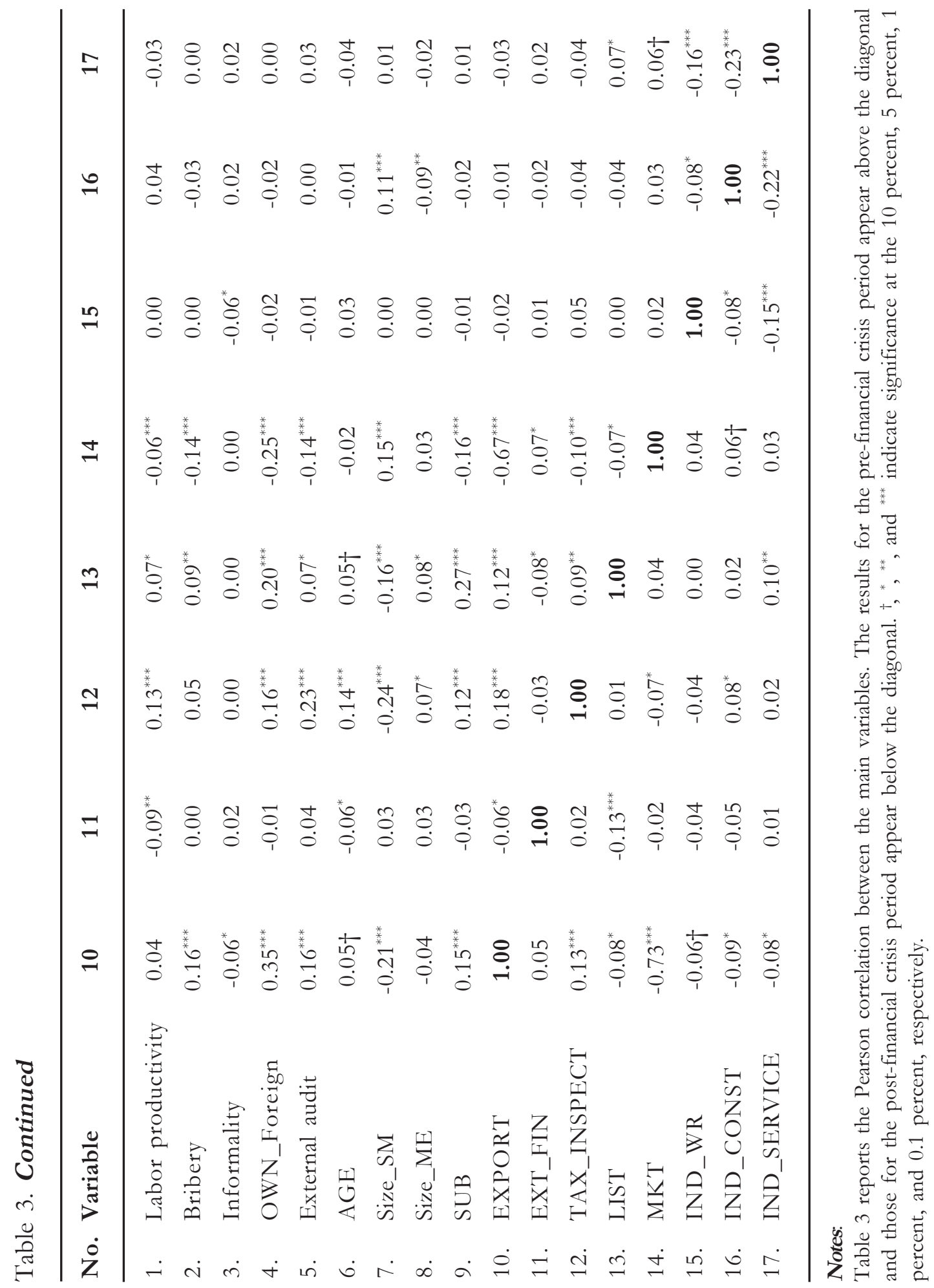


Table 4. Regression Result for Labor Productivity (Ordinary Least Squares, OLS)

\begin{tabular}{|c|c|c|c|}
\hline Variable & $\begin{array}{c}\text { Total } \\
(\mathrm{N}=2,061)\end{array}$ & $\begin{array}{l}\text { Pre-Financial Crisis } \\
\qquad(N=1,128)\end{array}$ & $\begin{array}{l}\text { Post-Financial Crisis } \\
\qquad(N=933)\end{array}$ \\
\hline Intercept & $11.90^{* * *}$ & $11.75^{* * *}$ & $12.85^{* * *}$ \\
\hline Bribery & $-0.40^{* * *}$ & -0.21 & $-0.42^{* *}$ \\
\hline Informality & $0.24^{* * *}$ & $0.30^{*}$ & $-0.23^{* *}$ \\
\hline OWN_Foreign & $0.67^{* * *}$ & $0.50^{* *}$ & $0.67^{* * *}$ \\
\hline External audit & $0.39^{* * *}$ & 0.13 & $0.41^{* * *}$ \\
\hline $\begin{array}{l}\text { Age } \\
\text { Firm size dummy }\end{array}$ & $0.17^{* * *}$ & $0.20^{* * *}$ & $0.11^{*}$ \\
\hline Size_SM & $-0.23^{* *}$ & -0.05 & $-0.25^{*}$ \\
\hline Size_ME & $-0.12 \dagger$ & 0.02 & -0.11 \\
\hline SUB & $0.23^{* * *}$ & $0.27^{*}$ & $0.19^{*}$ \\
\hline EXPORT & 0.00 & -0.38 & 0.04 \\
\hline EXT_FIN & 0.04 & $-0.30^{* *}$ & 0.02 \\
\hline TAX_INSPECT & $0.10 \dagger$ & $0.18^{*}$ & 0.02 \\
\hline LIST & 0.12 & 0.08 & 0.13 \\
\hline $\begin{array}{l}\text { MKT } \\
\text { Sector dummy } \\
\text { (Manufacturing) }\end{array}$ & -0.20 & -0.23 & -0.23 \\
\hline IND_WR & -0.16 & 0.01 & $-0.46^{* *}$ \\
\hline IND_CONST & -0.01 & 0.17 & -0.14 \\
\hline IND_SERVICE & -0.05 & -0.03 & 0.00 \\
\hline Adj. $R^{2}$ & $16.31 \%$ & $6.04 \%$ & $17.88 \%$ \\
\hline$F$ Value & $24.61^{* * *}$ & $5.26^{* * *}$ & $12.94^{* * *}$ \\
\hline VIF & $\begin{array}{c}2.22 \\
\text { (Size_SM) }\end{array}$ & $\begin{array}{c}2.38 \\
\text { (Size_SM) }\end{array}$ & $\begin{array}{c}2.39 \\
\text { (EXPORT) }\end{array}$ \\
\hline
\end{tabular}

Notes: ${ }^{\dagger} p<0.10 ;{ }^{*} p<.05 ;{ }^{* *} p<0.01 ;{ }^{* * *} p<0.001$.

\section{Robustness Check}

In order to obtain robustness, we conduct additional analyses using the panel data of 745 firms which participated in both the 2006 and 2010 surveys. It is an appropriate way to test the effects of the variables of in- terest on labor productivity, in that the panel data can contribute to controlling for the firm effect on the outcome variables. Table 5 summarizes the sensitivity's test results. The total sample size of the panel data is 1,490 observations, which is smaller than the original sample (2,061 observations). The coeffi- 
Table 5. Sensitivity Test Result (OLS): Panel Data

\begin{tabular}{|c|c|c|c|}
\hline Variable & $\begin{array}{c}\text { Total } \\
(\mathbf{N}=1,490)\end{array}$ & $\begin{array}{c}\text { Pre-Financial Crisis } \\
(N=745)\end{array}$ & $\begin{array}{c}\text { Post-Financial Crisis } \\
\qquad(N=745)\end{array}$ \\
\hline Intercept & $11.93^{* * *}$ & $12.02^{* * *}$ & $12.86^{* * *}$ \\
\hline Bribery & $-0.51^{* * *}$ & -0.27 & $-0.46^{*}$ \\
\hline Informality & $0.16^{* * *}$ & 0.14 & $-0.25^{* *}$ \\
\hline OWN_Foreign & 0.01 & $0.46^{*}$ & $0.55^{* * *}$ \\
\hline External audit & $0.41^{* * *}$ & 0.13 & $0.44^{* * *}$ \\
\hline Age & $0.14^{* * *}$ & $0.15^{*}$ & $0.11^{*}$ \\
\hline \multicolumn{4}{|l|}{ Firm size dummy } \\
\hline Size_SM & $-0.27^{* *}$ & $-0.25^{*}$ & -0.18 \\
\hline Size_ME & -0.13 & -0.13 & -0.06 \\
\hline SUB & $0.20^{* * *}$ & 0.19 & $0.21^{*}$ \\
\hline EXPORT & 0.24 & -0.48 & 0.24 \\
\hline EXT_FIN & 0.08 & $-0.28^{*}$ & 0.00 \\
\hline TAX_INSPECT & 0.08 & $0.20^{*}$ & -0.01 \\
\hline LIST & 0.15 & $0.29+$ & 0.04 \\
\hline $\begin{array}{l}\text { MKT } \\
\text { Sector dummy } \\
\text { (Manufacturing) }\end{array}$ & 0.02 & -0.08 & -0.14 \\
\hline IND_WR & -0.16 & 0.14 & $-0.56^{* *}$ \\
\hline IND_CONST & -0.04 & $0.29^{*}$ & $-0.27^{*}$ \\
\hline IND_SERVICE & 0.01 & 0.02 & 0.04 \\
\hline $\operatorname{Adj.} R^{2}$ & $16.29 \%$ & $6.38 \%$ & $16.43 \%$ \\
\hline$F$ Value & $16.85^{* * *}$ & $3.98^{* * *}$ & $9.60^{* * *}$ \\
\hline VIF & $\begin{array}{c}2.32 \\
(\text { EXPORT) }\end{array}$ & $\begin{array}{c}2.30 \\
\text { (Size_SM) }\end{array}$ & $\begin{array}{c}2.67 \\
(\text { EXPORT) }\end{array}$ \\
\hline
\end{tabular}

Notes: ${ }^{\dagger} p<0.10 ;{ }^{*} p<.05 ;{ }^{* *} p<0.01 ;{ }^{* * *} p<0.001$.

cients for some variables and $F$ values from the panel data are a little smaller than those from the original sample. Also, the variable Informality becomes insignificant in the prefinancial crisis of the panel data, $\beta_{1}=0.14$, $n s$ while it is significant in the original sample, $\beta_{1}=0.30, p<0.05$. In general, the results of the robustness check test are similar to the main results in Table 4, providing further support for the results of this study. 


\section{Discussion}

The impact of the global financial crisis - an unexpected event - on firm productivity in emerging markets was examined. This research aimed to compare the effect of the 2008 global financial crisis on firm performance in emerging economies. In particular, using a sample of Mexican businesses collected from the World Bank Enterprise Survey dataset, a comparison of the factors that affect labor productivity in emerging markets in the pre- and post-financial crisis periods was made.

The results suggest that bribery had non-significant effects on labor productivity before the crisis, while it has a significant negative correlation with labor productivity after the financial crisis. Informal competition was positively associated with labor productivity before the crisis, while it is negatively related to labor productivity after the crisis. On the other hand, foreign ownership is positively related to labor productivity before and after the crisis. External audit had non-significant effects on labor productivity before the crisis, while it has positive effects on labor productivity after the crisis.

The findings from this study support Mitton's (2002) argument that corporate governance could have played a critical role in firm performance in emerging markets during the East Asian financial crisis of 1997. Similarly, Rajan and Zingales (1998) argue that investigators are more likely to take the quality of corporate governance into consideration during a financial crisis than during a non-financial crisis period. In addition, Clasessens and Djankov (1999a, 1999b) report that foreign ownership is positively related to the labor productivity of firms in the Czech Republic, a transition economy.
The results of this study have several implications. First, this study contributes to the literature on emerging markets and corruption by testing the effects of the financial crisis on the corruption-labor productivity relationship in emerging markets. In addition, the findings from this study show that the factors that may influence the labor productivity of firms in emerging markets in the preand post-financial crisis periods are different. Firm bribery did not have a significant impact on firm performance before the financial crisis, while it is significantly related to labor productivity after the financial crisis. Similarly, as seen in Table 4, external auditing is positively associated with labor productivity after the global financial crisis, while the relationship between the two variables was non-significant before the crisis. These results imply that the financial crisis may have changed the factors that influence firm performance.

The findings from this study have some implications for practitioners. First, as corporate bribery has negative effects on labor productivity after the crisis, businesses should not bribe officials. Second, corporate governance's quality has positive effects on labor productivity in emerging markets. This implies that businesses should try to improve the quality of their corporate governance. For example, businesses should manage the ownership structure by increasing foreign ownership in emerging markets. Foreign investors may assist in improving corporate governance, because they can play a critical role in monitoring the decision-making of management. Further, the disclosure quality needs to be high, since external audits can have positive impacts on labor productivity after the crisis. External audits can contribute to firm performance in that they are increasingly regarded 
as providing clear information of the firm's accounting and financial performance, compared to an internal audit. In other words, the fact that businesses are audited externally may be considered as being ethical, thus giving them a good reputation, which in turn could lead to an increase in sales.

Despite its contributions, this study has some limitations. First of all, only a few of the sample businesses participated in both the 2006 and 2010 surveys. This prevents us from comparing the differential effects of the financial crisis on the relationship between the test variables - bribery, informality, external audit, etc. - and labor productivity. Therefore, further research should be conducted on panel data, which have high rates of sample retention. Similarly, as the impact of the 2008 financial crisis on firm performance may become clear in the future, longitudinal studies may be necessary for more robust outcomes.

In addition, since Mexico's case was tested, the findings from this study may not be applicable to other emerging markets such as China, India, Vietnam, etc. Although Mexico has been considered a fast-growing economy, business environments or institutional features are different across transition economies (Kang and Chung 2015). Accordingly, it would be necessary to test the effect of the financial crisis on the determinants of labor productivity by using data from other transition economies.

Another limitation is that this study deals with informality, bribery, external audits, and others as the determinants of labor productivity. There are other possible elements that influence labor productivity, such as Research and Development (R\&D) efforts (Lederman and Maloney 2003) and training (Kang 2016). Therefore, future studies need to be conducted on the effects of the finan- cial crisis on the relationship between these factors and labor productivity.

Finally, this study uses labor productivity as an important indicator of firm performance. There are other financial or accounting indicators that present firm productivity, such as Return on Assets (ROA), Return on Investments (ROI), earnings, or earnings growth. Thus, further research could investigate the relationship of the test variables of this study to the financial or accounting performance of emerging markets in the pre- and post-financial crisis periods.

\section{Conclusion}

The global financial crisis of 2008 was considered to be the largest global economic downfall since the Great Depression of the 1930s (Dal Bianco et al. 2017). The main purpose of this study was to determine the effects of the financial crisis on firm performance in emerging markets. To this end, a sample of 2,061 Mexican firms was used to investigate the factors that could influence labor productivity in the pre- and post-financial crisis periods. The study concludes that, before the crisis, informality and foreign ownership had positive effects on labor productivity. However, after the crisis, bribery and informality are negatively related to labor productivity, while the quality of corporate governance-foreign ownership and external audit-is positively associated with labor productivity.

The findings of this study will contribute to the understanding and improvement of labor productivity in emerging markets after the financial crisis. The focus on emerging markets today is relatively weaker than in the early 2000s because, since then, it has been discovered that emerging markets have 
a structural vulnerability resulting from institutional voids. However, with improved infrastructure, there are more market opportunities and global businesses in emerging markets, and it is necessary to investigate how the financial crisis affects firm performance in emerging markets.

Nevertheless, this study has some limitations, which provide further research opportunities. First, this study uses a sample in which only a few companies participated in both the 2006 and 2010 surveys. For more correct comparisons, the relationship of bribery, informality, and corporate governance quality to labor productivity may need to be tested on the same companies. Therefore, future research requires panel data that have high sample retention rates, in order to compare the determinants of labor productivity before the crisis with those after the crisis.

Next, as this study uses the Mexican case of emerging markets, it may be difficult to generalize the study results. Although the focus was on the test variables that are regarded as the remarkable features of emerging markets, the local context of emerging markets differ between countries. Accordingly, further studies need to be conducted on a sample of diverse cases to generalize the findings from this study.

Finally, this study attempted to identify the determinants of labor productivity before and after the financial crisis. However, there are other potential indicators of financial, or accounting performance, such as stock price growth, earnings growth, and so on. Stock price or earnings growth is an indicator of firm performance for financial markets. In addition to organizational efficiency, future research needs to explore the determinants of the financial outcomes of emerging markets.

\section{Acknowledgement}

This research was supported by the Keimyung University Research Grant of 2017.

\section{References}

Ahmed, S., B. Coulibaly, and A. Zlate, 2017. International financial spillovers to emerging market economies: How important are economic fundamentals? Journal of International Money and Finance 76: 133-152. Available at: <https://doi.org/10.1016/j.jimonfin.2017.05.001>. Date accessed: Aug. 2017.

Altug, S., and S. Kabaca. 2017. Search Frictions, Financial Frictions, and Labor Market Fluctuations in Emerging Markets. Emerging Markets Finance and Trade 53 (1): 128-149.

Alaimo, V., P. Fajnzylber, J. L. Guasch, H. Lopez, andA. M. Oviedo. 2009. The investment climate in Latin America, In P. Fajnzylber, J. L. Guasch, and J. H. Lopez (Eds.), Does the Investment Climate Matter?: Microeconomic Foundations of Growth in Latin America (pp. 49-111). Washington, DC: World Bank publications.

Amin, M. 2011. Labor Productivity, Firm-Size and Gender: The Case of Informal Firms in Argentina and Peru. Enterprise Note (No.22), Washington DC: World Bank Group. 
Baik, Y. S., S. H. Lee, and C. Lee. 2015, Entrepreneurial firms'choice of ownership forms. International Entrepreneurship and Management Journal 11 (3): 453-471.

Barako, D. G., P.Hancock, and H. Y. Izan.2006. Factors influencing voluntary corporate disclosure by Kenyan companies. Corporate Governance: An International Review 14 (2): 107-125.

Campello, M., J. R. Graham, and C. R. Harvey. 2010. The real effects of financial constraints: Evidence from a financial crisis. Journal of Financial Economics 97 (3): 470-487.

Chen, Y-R., J-R. Chiou, T-K Chou, and M. S. Sue. 2009. Corporate governance and long-run performance of equity issues: The role of foreign ownership in Taiwan. Asia Pacific Management Review 14 (1): 27-46.

Claessens, S., and S. Djankov. 1999a. Enterprise performance and management turnover in the Czech Republic. European Economic Review 43 (4): 1115-1124.

Claessens, S., and S. Djankov. 1999b. Ownership concentration and corporate performance in the Czech Republic. Journal of Comparative economics 27 (3): 498-513.

Cuervo-Cazurra, A. 2006. Who cares about corruption? Journal of International Business Studies 37(6): 807822.

Dal Bianco, S., C. Amini, and M. Signorelli. 2017. The Impact of the Global Financial Crisis and the Role of External and Internal Factors in Emerging Economies. Emerging Markets Finance and Trade 53(2): 229-249.

Djankov, S., I. Lieberman, J. Mukherjee, and T. Nenova. 2003. Going informal: benefits and costs, In B. Belve(Ed.), The Informal Economy in the EU Accession Countries: Size, Scope, Trends and Challenges to the Process of EU Enlargement (pp. 63-80). Sofia: Center for the Study of Democracy.

Dimitriou, D., D. Kenourgios, and T. Simos. 2013. Global financial crisis and emerging stock market contagion: A multivariate FIAPARCH-DCC approach. International Review of Financial Analysis 30: 46-56.

Dooley, M. P. 2000. A model of crises in emerging markets. The Economic Journal 110 (460): 256-272.

Dooley, M., and M. Hutchison. 2009. Transmission of the US subprime crisis to emerging markets: Evidence on the decoupling-recoupling hypothesis. Journal of International Money and Finance 28(8): 1331-1349.

Gallagher, K. P., and Y. Tian.2017. Regulating capital flows in emerging markets: the IMF and the global financial crisis. Review of Development Finance. Available at: <https://doi.org/10.1016/ j.rdf.2017.05.002>. Date accessed: Aug. 2017.

González, A., and F. Lamanna. 2007. Who fears competition from informal firms? Evidence from Latin America. Policy Research Working Paper (No.4316).Washington, DC: World Bank.

International Monetary Fund. 2014. World Economic Outlook, Recovery Strengthens, Remains Uneven (April). Washington, DC: International Monetary Fund.

Johnson, J. L., and A. M. O'Leary Kelly. 2003. The effects of psychological contract breach and organizational cynicism: Not all social exchange violations are created equal. Journal of Organizational Behavior 24(5): 627-647.

Johnson, S., P. Boone, A. Breach, and E. Friedman. 2000. Corporate governance in the Asian financial crisis, 1997-98. Journal of Financial Economics 58: 141-186.

Kang, Y.-H. 2016. Innovation of small-medium sized enterprises (SMEs) and labor productivity in Mexico. Latin American and Caribbean Studies 35(1): 175-193. 
Kang, Y.-H., and H.-Y. Chung. 2015. Small \& medium-sized enterprise (SMEs)' performance in Mexico: Relations of security cost, corruption, and informal competition to firm's performance. Asia Pacific Journal of Small Business 37(4): 57-76.

Kaufmann, D., and S. J. Wei. 1999. Does “Grease Money" Speed up the Wheels of Commerce? (No. w7093). National Bureau of Economic Research.

Kwon, K., J. Kim, M. Park, and S. Yi. 2014. Mexican Economy on the Rise and Expanding Korea-Mexico Economic Cooperation. Seoul: Korea Institute for International Economic Policy.

La Porta, R., F. Lopez-de-Silanes, A. Shleifer, and R. Vishny. 2000. Investor protection and corporate governance. Journal of Financial Economics 58: 3-27.

Lee, S. H., and D. H. Weng. 2013. Does bribery in the home country promote or dampen firm exports?. Strategic Management Journal 34 (12): 1472-1487.

Levie, J., and E. Autio. 2011. Regulatory burden, rule of law, and entry of strategic entrepreneurs: An international panel study. Journal of Management Studies 48 (6): 1392-1419.

Luo, Y. 2005. An organizational perspective of corruption. Management and Organization Review 1 (1): 119-154.

Mitton, T. 2002. A cross-firm analysis of the impact of corporate governance on the East Asian financial crisis. Journal of financial economics 64 (2): 215-241.

Neaime, S. 2012. The global financial crisis, financial linkages and correlations in returns and volatilities in emerging MENA stock markets. Emerging Markets Review 13 (3): 268-282.

Padgett, M. Y., and K. A. Morris. 2005. Keeping it "all in the family" does nepotism in the hiring process really benefit the beneficiary? Journal of Leadership \& Organizational Studies 11 (2): $34-45$.

Reinhart, C. M., and K. S. Rogoff. 2008. Is the 2007 US Sub-Prime Financial Crisis so Different? An International Historical Comparison (No. w13761). National Bureau of Economic Research.

Rodriguez, P., K. Uhlenbruck, K., and L. Eden. 2005. Government corruption and the entry strategies of multinationals. Academy of Management Review 30(2): 383-396.

Sachs, J., A. Tornell, and A. Velasco. 1996. Financial Crises in Emerging Markets: The Lessons from 1995 (No. w5576). National bureau of economic research.

Sanchez, J., C. Gomez, and G. Wated. 2008. A value-based framework for understanding managerial tolerance of bribery in Latin America. Journal of Business Ethics 83(2): 341-352.

Schneider, F.2005. Shadow economies of 145 countries all over the world: What do we really know? CREMA Working Paper 2006-01. Basel: Center for Research in Economics, Management and the Arts.

Schneider, M. F., and Enste, D. 2000. Shadow Economies Around the World: Size, Causes, and Consequences (No. 0-26). Washington, DC: International Monetary Fund.

Wei, S. J. 2000. How taxing is corruption on international investors? Review of Economics and Statistics 82(1): 1-11. 